$\int \begin{aligned} & \text { p-ISSN: 2723-4703 } \\ & \text { e-ISSN: - } \\ & \text { http://ejurnal.iaipd-nganjuk.ac.id/index.php/j-kis/ } \\ & \text { KURNALUNIKASI ISLAM }\end{aligned}$

\title{
MODEL KEBERAGAMAAN MASYARAKAT REJOMULYO DI TENGAH-TENGAH LINGKUNGAN BERKEMBANGNYA LEMBANGA PENDIDIKAN AGAMA
}

\author{
Muhammad Amrillah, \\ IAI Pangeran Diponegoro Nganjuk, \\ amrillah084@gmail.com
}

\begin{abstract}
ABSTRAK
Dari fenomena yang dapat diidentifikasi pada masyarakat Rejomulyo kecamatan kota Kediri praktik keagamaan yang ada dapat dikelompokkan ke dalam bentuk-bentuk golongan sosial religius, yakni Abangan, Santri, dan Priyayi terbukti dengan adanya masyarakat Rejomulyo masih percaya kepada animistik tentang kekuatan goib, Masih berjalannya ritualritul tradisi selamatan, masih mempercayai nilai-nilai ajaran nenek moyang (kejawen ) ini merupakan ciri orang abangan, adanya pondok pesantren yang merupakan indikasi orang santri, adanya guru dan pegawai merupakan tanda golongan priyayi.

Lembaga Pendidikan Agama sebagai lembaga agama yang memiliki fungsi mendorong tumbuh kembang kesadaran beragama di lingkungan masyarakat. Lembaga Pendidikan Agama merupakan salah satu lembaga keagamaan yang tentunya memiliki peran terhadap masyarakat sekitarnya. Lembaga agama (institusi religius) dapat diartikan sebagai suatu bentuk organisasi yang tersusun relatif tetap atas pola-pola kelakuan, peranan-peranan dan relasi-relasi yang terarah dan mengikat individu, mempunyai otoritas formal dan sanksi hukum untuk mencapai kebutuhan dasar yang berkenaan dengan dunia supra-empiris.

Hasil penelitian deskriftif mengungkapkan bahwa Sebagaian besar masyarakat Rejomulyo masih menjalankan ritual Abangan seperti apa yang di jelaskan oleh Clifford Geertz yang melakukan studinya di daerah Pare. Tradisi yang berkembang pada masyarakat Rejomulyo tidak diketahui kapan mulai berkembangnya. Karena generasi yang ada sekarang hanya mewarisi apa yang telah ada, dan mereka tinggal mengamalkan dari apa yang menjadi tradisi dari nenek moyangnya. Di tengah-tengah lingkungan berkembangnya Lembaga Pendidikan Agama, masyarakat masih tetap berpegang teguh dengan nilai lama, yang digunakan untuk meneguhkan
\end{abstract}


jati diri dan kepribadian masyarakat. Filosofi hidup orang Jawa ojo dumeh yang berarti mawas diri, dan tansah eling yang berarti selalu ingat terhadap tujuan hidup, member pedoman penting bagi masyarakat Jawa. Tradisi yang terdapat di masyarakat ada yang bertentangan dengan akidah Islam, tapi ada juga yang mendukung ajaran Islam. Hal ini tidak bisa dihindari, karena perjalanan sejarah masuknya Islam di nusantara akan mengalir kepada timbulnya sinkretisme budaya dan agama.

\section{Kata kunci: Model keberagamaan, Lembaga pendidikan agama}

\section{PENDAHULUAN}

Madrasah merupakan lembaga pendidikan Islam yang lahir setelah munculnya ideide pembaruan pemikiran Islam di Indonesia. Karena itu, unsur-unsur pendidikan modern ditemukan di madrasah, seperti sistem klasikal, manajemen pendidikan. Mata pelajaran agama dan umum jadi seimbang. Dinamika madrasah hingga saat mengantarkan madrasah menjadi sekolah yang berciri khas agama Islam, setelah terlebih dahulu diakuinya bahwa madrasah setara dan sederajat dengan sekolah berdasarkan SKB menteri pada tahun 1975. Hal itu dikuatkan dengan UU No 2 Tahun 1989 dan UU No 20 Tahun 2003 (UndangUndang tentang Sistem Pendidikan Nasional) yang menguatkan kedudukan madrasah.

Lembaga pendidikan berikutnya ialah lembaga pendidikan tinggi Islam. Lembaga ini dibagi secara garis besar kepada dua macam. Pertama, yang berbentuk negeri, yaitu UIN, IAIN, dan STAIN. Kedua, yang berbentuk swasta yang dibagi juga pada tiga jenis, yaitu universitas, institut, dan sekolah tinggi.

Lembaga Pendidikan Agama sebagai lembaga agama yang memiliki fungsi mendorong tumbuh kembang kesadaran beragama di lingkungan masyarakat

Lembaga Pendidikan Agama merupakan salah satu lembaga keagamaan yang tentunya memiliki peran terhadap masyarakat sekitarnya. Lembaga agama (institusi religius) dapat diartikan sebagai suatu bentuk organisasi yang tersusun relatif tetap atas pola-pola kelakuan, peranan-peranan dan relasi-relasi yang terarah dan mengikat individu, mempunyai otoritas formal dan sanksi hukum untuk mencapai kebutuhan dasar yang berkenaan dengan dunia supra-empiris. Lain halnya dengan lembaga sosial. Lembaga sosial merupakan suatu bentuk organisasi yang terbentuk relatif tetap atas pola-pola perilaku, peranan-peranan dan relasi yang terarah dan mengikat individu, mempunyai otoritas formal dan sanksi hukum guna tercapainya kebutuhan-kebutuhan sosial dasar. Jika dalam lembaga non keagamaan atau lembaga sosial orang menginginkan tercapainya secara pasti kebutuhan-kebutuhan 
$\int \begin{aligned} & \text { p-ISSN: 2723-4703 } \\ & \text { e-ISSN: - } \\ & \text { http://ejurnal.iaipd-nganjuk.ac.id/index.php/j-kis/ } \\ & \text { KURNAL }\end{aligned}$

sosial dasar, maka dalam lembaga keagamaan orang menginginkan tercapainya kebutuhan dasar yang berkenaan dengan kepentingan dunia supra-empiris. Selain itu, lembaga keagamaan dianggap mampu memberikan jaminan-jaminan yang pasti baik sebab di dalam lembaga ada unsur kekuasaan yang berwenang untuk memberikan sanksi hukum sebagai sarana preventif dan represif terhadap pemeluk-pemeluk agama yang tidak patuh.

Keberadaan Lembaga Pendidikan Agama yang berada di sekitar masyarakat Rejomulyo tentu memiliki hubungan yang sangat erat terhadap model keberagamaan masyarakat. Keberadaan lembaga pendidikan seperti MTsN2, MAN2, STAIN Kediri tentu memiliki pengaruh yang cukup besar, lembaga-lembaga tersebut merupakan Lembaga Pendidikan Agama mengembangkan agama secara akademis dan mentradisikan agama dalam praktek kehidupan. Dengan konsep tersebut di harap berdampak pada model keberagamaan masyarakat Rejomulyo di tengah-tengah lingkungan berkembangnya Lembaga Agama.

Dalam kehidupan masyarakat, tentunya agama mempunyai fungsi atau peran. Dalam hal ini aliran fungsionalisme, melihat masyarakat sebagai suatu equilibrium sosial dari semua institusi yang ada di dalamnya sebagai keseluruhan sistem sosial masyarakat menciptakan pola-pola kelakuan yang terdiri atas norma-norma yang dianggap sah dan mengikat oleh anggota-anggotanya yang menjadi pengambil bagian dari sistem itu. Keseluruhan dari institusi-institusi yang membentuk sistem sosial yang sedemikian rupa, sehingga setiap bagian atau institusi saling membutuhkan dengan semua bagian yang lain. Di sini agama hanya merupakan suatu bentuk tindak langkah manusia yang dilembagakan yang berada di antara lembaga-lembaga sosial lainnya. Agama juga memiliki fungsi terhadap keseluruhan sistem soial dan masyarakat.

Durkheim menyatakan bahwa fungsi sosial agama adalah mendukung dan melesterikan masyarakat yang sudah ada. Agama menurut mereka bersifat fungsional terhadap persatuan dan solidaritas sosial. Teori Fungsional memandang sumbangan agama terhadap masyarakat berdasarkan atas karakteristik pentingnya, yaitu transendensi pengalaman sehari-harinya dalam lingkungan alam. Sebab teori Fungsional memandang hal tersebut sebagai hasil dari tiga dasar eksistensi manusia. Pertama, manusia hidup dalam kondisi ketidakpastian. Terkait dengan usaha manusia, sebaik apapun sebuah rencana dan dilaksanakan dengan seksama mungkin, tetap tidak lepas dari kekecewaan. Kedua, manusia 
memiliki keterbatasan untuk mengendalikan dan untuk mempengaruhi kondisi hidupnya. Sehingga antara keinginan dengan lingkungan ditandai oleh ketidakmampuan. Ketiga adalah kelangkaan,kebutuhan manusia setiap hari semakin mengikat, sedangkan persediaan untuk memenuhi semua kebutuhan tersebut sangat terbatas. Ketiga keadaan tersebut mengakibatkan manusia merasakan kekecewaan yang mendalam dan itu merupakan penderitaan baik lahir maupun batin. Sehingga agama dijadikan sebagai solusi terhadap masalah-masalah yang mereka hadapi tersebut.

Fenomena yang dapat diamati pada masyarakat desa Rejomulyo kecamatan Kota, sampai sekarang masih mengemas berbagai praktek ritual keagama masyarakat di desa tersebut. Terutama dilakukan oleh para elit lokal dalam posisi mereka sebagai agen sosial. Di antara ritual-ritual itu antara lain: Jumat Legian, yasinan, Diba'an, Mauludan, Sapar, dan Rejeb, Suroan (acara bersih desa) yang dilaksakan di mushola-mushola yang dipimpin oleh pak RT yang terakhir adalah Dzikrul Ghofilin yang diselenggarakan setiap satu minggu sekali yaitu pada hari rabu malam yang di hadiri oleh orang laki-laki dan perempuan.

Dari fenomena yang dapat diidentifikasi pada masyarakat Rejomulyo kecamatan kota Kediri praktik keagamaan yang ada dapat dikelompokkan ke dalam bentuk-bentuk golongan sosial religius, menurut Clifford Geertz diantaranya Abangan, Santri, dan Priyayi.

Dengan memperhatikan model keberagamaan masyarakat Rejomulyo seperti di gambarkan di atas, perlu kiranya mengetahui sejauh mana dan bagaimana peran-peran dan pengaruh Lembaga Pendidikan tersebut dalam keberagamaan masyarakat Rejomulyo. Dengan memperhatikan permasalahan di atas tersebut, perlu kiranya melakukan penelitian ini untuk mencari jawaban dari persoalan di atas.

\section{METODE PENELITIAN}

Dalam penelitian ini penulis menggunakan jenis penelitian "Deskriptif Kualitatif" yang dimaksudkan untuk mengungkap gejala secara holistic dan kontekstual melalui pengumpulan data dari latar alami dengan memamfaatkan diri peneliti sebagai instrument kunci. Dengan demikian penelitian ini bersifat deskriptif dan banyak menggunakan analisa secara induktif. Pendekatan yang penulis gunakan dalam penelitian ini adalah pendekatan deskriptif kualitatif, yaitu penelitian yang berusaha mengungkap gejala secara menyeluruh dan sesuai dengan konteks melalui pengumpulan data dari latar alami dengan memanfaatkan diri sebagai instrumen kunci. Dengan pendekatan penelitian deskriptif ini 


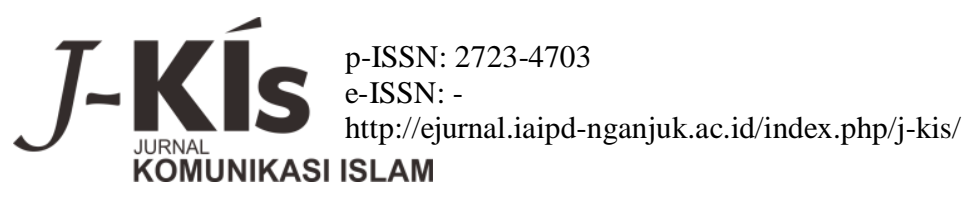

data yang dihasilkan adalah berupa ucapan atau tulisan dan perilaku yang diamati orangorang (obyek) itu sendiri.

Bentuk peneliti yang digunakan dalam penelitian ini adalah lapangan menggambarkan sebuah fenomena di masyarakat secara umum dengan meyeluruh, mencoba mengkaji secara mendalam dan terperinci dari suatu konteks. Oleh karena itu, laporan penelitian kualitatif disusun dalam bentuk narasi yang bersifat kreatif dan mendalam setrta menunjukkan ciri-ciri naturalistic dan apa adanya. Informasi yang di gali dan diperoleh dari lapangan menjadi sangat bermakna guna mendiskripsikan latar alami yang diperlukan dalam menyususn laporan penelitian kualitatif.

\section{HASIL DAN PEMBAHASAN}

\section{A. Kondisi Sosial Religius Masyarakat Kelurahan Rejomulyo}

Setelah mengenal lebih dekat, tradisi yang berkembang di masyarakat Rejomulyo adalah sebagai tradisi masyarakat pedesaan, memiliki karakteristik berbeda dengan tradisi masyarakat perkotaan. Oleh sebab itu tradisi masyarakat pedesaan ini mulai berkembang sejak runtuhnya kerajaan Mataharam, kemudian digantikan oleh berdirinya kerajaan Islam di Demak. Kebudayaan Jawa atau yang lebih dikenal dengan Kajawen adalah model sinkretis anatara budaya Jawa dengan Islam. Kajawen lebih menekakan kedekatan moral dengan Sangkan Paraning Dumadi, yaitu mistik kejawen yang tak lain juga merupakan representasi upaya berfikir filosof manusia jawa. Karena itu, melalui mistik kejawen dapat diketahui bagaimana manusia jawa berpikir tentang hidup, manusia, dunia, dan Tuhan.

Ada dua hal yang perlu dipahami, sehubungan adanya proses Islamisasi di jawa. Pertama, agam Hindu dan Budha serta kepercayaan asli jawa telah berkembang terlebih dahulu, jika dibandingkan dengan Islam. Kepercayaan Hindu dan Buddha dipeluk oleh kalangan kerajaan, sementara kepercayaan lokal (Animisme) dipeluk oleh kalangan awam. Kedua, meskipun telah terjadi Islamisasi secara besar-besaran pada abad 15-16 di Jawa, tetapi disaat yang sama, Islam sedang mengalami kemunduran karena mengalami kekelahan dari Hulagukhan, dengan sendirinya umat Islam banyak yang menekuni dunia mistik. Oleh sebab itu Islam yang dibawa ke tanah Jawa Islam mistik. Adanya persamaan warna antara Islam dan kepercayaan lokal, menyebabkan Islam di Jawa sangat toleran dengan tradisi masyarakat setempat. Hal inilah yang menyebabkan tugas Wali Songo semakin mudah untuk menyiarkan Islam. Namun ini dianggap menimbulkan dampak yang negatif sekaligus positif bagi 
masyarakat muslim di Jawa. Model Islamisasi yang demikian membuat masyarakat muslim menjadi permisif. Jika ditanya mereka mengaku sebagai orang muslim, tetapi tindakantindakannya dan ucapannya sering berbeda dengan ajaran Islam. Dampak positifnya adalah proses Islamisasi yang akomodatif tersebut tidak menimbulkan gejolak yang berati di masyarakat. Tardisi lama tidak mereka hapuskan secara radikal dan frontal, tetapi yang mereka hilangkan hanya hal-hal yang jelas bertentangan dengan Islam. Di sinilah terjadi akulturasi dan sinkretisasi antara tradisi dan kepercayaan lokal disatu pihak, dengan ajaran dan agama di pihak lainnya.

Tradisi lokal yang berkembang pada masyarakat Rejomulyo, dimungkinkan sudah berkembang beratus tahun. Generasi yang ada tidak mengetahui sejak kapan tradisi itu ada. Ini menunjukkan tradisi tersebut sudah cukup tua. Dilihat dari nama dan bentuk tradisi yang ada, tradisi ini adalah merupakan sub budaya pedalaman, yang memiliki karakteristik animis. Dan ini berbeda dengan sub budaya pesisir yang dikenal lebih religious.

Kejawen dalam bentuk praktis adalah bertumpu pada ritual Slametan. Ini akan tergambar dalam tradisi yang dilakukan oleh masyarakat Jawa, tidak bisa lepas dari ritual ini. Slametan bisa bermakna memohon keselamatan, tolak balak, ucapan syukur atau terimakasih atas berkah Tuhan, atau peringatan-peringatan, dan bahkan bisa bermakna mendoakan.

Slametan adalah upacara keagamaan Jawa yang paling umum di dunia. Slametan melambangkan kesatuan mistis dan sosial mereka yang terlibat di dalamnya. Menurut Geertz, Slametan adalah merupakan wadah bersama masyarakat yang mempertemukan berbagai aspek kehidupan sosial dan pengalaman perseorangan, dengan suatu cara yang memperkecil "ketidakpastian", ketegangan, dan konflik. Slametan dapat diadakan untuk memenuhi semua hajat orang sehubungan dengan suatu kejadian yang ingin diperingati, ditebus, seperti kelahiran, perkawinan, kematian, panen, sakit atau musibah. Perbedaannya adalah pada penekanan peristiwa-peristiwa tersebut. Sebagian ritual tersebut ada yang diadakan dengan cara yang meriah, adapun yang diadakan dengan cara sederhana, tetapi struktur acara yang mendasarinya sama. Dan selalu ada hidangan yang khas, sesuai dengan kebutuhan ritual.

Makna slametan yang paling mendasar adalah merupakan upacara inti, terutama kelompok abangan. Slametan juga dapat bermakna sebagai penyeragaman status sosial. Kaya dan miskin berhak untuk mengadakan slametan. Orang kaya jika diundang untuk slametan di rumah orang miskin juga harus datang, begitu pula orang miskin yang diundang slametan di rumah orang kaya juga harus hadir. 
$\int \begin{aligned} & \text { p-ISSN: } 2723-4703 \\ & \text { e-ISSN: - } \\ & \text { http://ejurnal.iaipd-nganjuk.ac.id/index.php/j-kis/ } \\ & \text { KURNALUNIKASI ISLAM }\end{aligned}$

Adapun pola keagamaan masyarakat Kelurahan Rejomulyo adalah:

Tabel 5: Pola keagamaan masyarakat Kelurahan Rejomulyo

\begin{tabular}{|c|c|c|c|c|}
\hline No & $\begin{array}{c}\text { Pola / } \\
\text { karakteristik }\end{array}$ & Santri & Abangan & Priyayi \\
\hline \multirow[t]{3}{*}{1} & \multirow[t]{3}{*}{ Ritual } & $\begin{array}{l}\text { - Sholat } 5 \text { waktu } \\
\text { - Menjalankan } \\
\text { praktek mistik }\end{array}$ & $\begin{array}{l}\text { - Menjalankan } \\
\text { praktek } \\
\text { mistik }\end{array}$ & $\begin{array}{l}\text { - Sholat } 5 \\
\text { waktu } \\
\text { - Menjalank } \\
\text { an praktek } \\
\text { mistik }\end{array}$ \\
\hline & & $\begin{array}{l}\text { - Menjalankan } \\
\text { tradisi slametan }\end{array}$ & $\begin{array}{l}\text { - Menjalankan } \\
\text { tradisi } \\
\text { selametan }\end{array}$ & $\begin{array}{l}\text { - Menjalank } \\
\text { an trdisi } \\
\text { slametan }\end{array}$ \\
\hline & & $\begin{array}{l}\text { - Puasa } \\
\text { ramadhan }\end{array}$ & & $\begin{array}{l}\text { - Puasa } \\
\text { ramadhan }\end{array}$ \\
\hline \multirow[t]{2}{*}{2} & \multirow[t]{2}{*}{$\begin{array}{l}\text { Simbol- } \\
\text { simbol }\end{array}$} & $\begin{array}{c}\text { - Seperangkat } \\
\text { alat sholat }\end{array}$ & - Sesajen & $\begin{array}{l}\text { - Seperangk } \\
\text { at alat } \\
\text { sholat } \\
\text { - Orang } \\
\text { kaya }\end{array}$ \\
\hline & & - Seni kejawen & - Seni kejawen & $\begin{array}{l}\text { - Seni } \\
\text { kejawen }\end{array}$ \\
\hline
\end{tabular}

Tabel ini tidak seperti tabelya Clifford Geertz yang mengalami pe rubahan karena masyarakat golongan Santri, Abangan, Priyayi juga masih menjalankan ritual keagamaan seperti slametan, tasyakhuran, dan walimah. 
Ajaran-ajaran kejawen yang di praktekan oleh masyarakat Kelurahan Rejomulyo, seperti Kepercayaan terhadap Mahluk Halus, Kepercayaan terhadap Tempat Keramat, Ritual Lingkaran Hidup, Ritual Tolak Balak, Upacara pertanian, Ritual Kelurga, Upacara Hari Besar Islam, Nogo Dino.

\section{Kepercayaan Terhadap Mahluk Halus}

Kepercayaan kepada Tuhan bisa percaya pada dewa-dewa, kekuatan gaib, atau percaya terhadap roh-roh halus. Pada setiap masyarakat hampir bisa dipastikan memiliki kepercayaan terhadap roh-roh halus. Pada setiap suku didunia ini memiliki kepercayaan semacam ini. Di dalam agama-agama besar seperti Islam, Kristen, Yahudi dan yang lain. Menurut keyakinan lokal jumlah dan kwalitas mahluk halus bermacam-macam. Pada setiap entitas budaya, memiki mahluk halus sendiri-sendiri. Kepercayaan terhadap Mahluk halus, seperti genderuwo dan sterusnya adalah merupakan suatu dunia sosial yang dirubah bentuknya secara simbolis. Orang kuat memperalat orang yang lemah. Meskipun ada kekaburan, kontradiksi dan diskontinuitas dalam kepercayaan terhadap mahluk halus ini, kepercayaan ini memberi makna yang lebih luas dan lebih umum. Cerita-cerita kesialan terhadap mahluk halus ini menggambarkan kemenangan dan keunggulan manusia atas mahluk lainnya. Menurut keyakinan lokal, jumlah dan kualitas mahluk halus pun bervariasi. Bahkan di masing-masing entitas kebudayaan memiliki mahluk halusnya sendiri-sendiri. Di masyarakat pedalaman, keyakinan tentang mahluk halus itu juga erat kaitannya dengan dunia sosial atau konteksnya. Demikian pula di masyarakat nelayan juga memiliki keyakinan tentang mahluk halus.

\section{Kepercayaan TerhadapTempat Keramat}

Kepercayaan terhadap tempat-tempat yang dianggap keramat ini, selalu ada pada setiap masyarakat, seperti masjid dan makam. Mereka menganggap masjid ini sebagai tempat yang keramat dan sakral, karena tempat sholat, rumah Allah. Setiap manusia yang inggin berjumpa dengan Allah, mereka pergi kemasjid. Oleh karena itu ketika mereka berada di masjid dan sekitarnya, mereka menjaga ucapan dan tingkah laku. Makam, dianggap karena tempat bersemayamnya roh-roh yang memiliki kharisma.

\section{Ritual Linkaran Hidup}




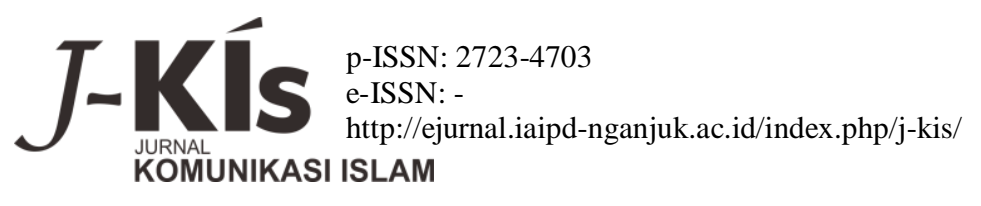

Ritual lingkaran hidup adalah ritual yang meliputi siklus kehidupan manusia, dari lahir sampai kepada kematian. Seperti halnya upacara lainnya, upacara ini juga ada dalam setiap masyarakat lainnya. Ritual lingkaran hidup ini selalu berbentuk selametan, itu dimulai dari kehamilan umur 3 bulan dan 6 bulan. Kemudian dilanjutkan dengan kelahiran, dari umur 1 hari, 6 hari, selapan (potong rambut), 3 selapan, 7 selapan, 9 selapan yang dikenal dengan medun lemah (Tedak siti, Turun lemah kemudian dilanjutkan dengan setahunan. Di dalam upacara lingkaran hidup, sesajen itu berupa bahan-bahan makanan yang telah disucikan melalui cara-cara tertentu, yang tidak lazim untuk kegiatan membuat makanan pada umumnya. Ada prosesi "penyucian” yang terlibat di dalamnya.

Upacara kehamilan, misalnya akan terdapat proses penyucian melalui ritus "bacaan doa", bacaan ayat-ayat suci Al-Qur'an dan juga pembuatan simbol-simbol kesucian, seperti penulisan nama Maryam, Yusuf, atau Muhammad sebagai lambang-lambang manusia suci dalam cerita kehidupan manusia. Selametan orang meninggal salah satu bentuk pengiriman pahala kepada mayit adalah melalui sedekah yang kusus dihadirkan pada mayit. Sedekah ini biasanya diberikan dalam bentuk selamatan dari ahli warisatau keluarga mayit. Sebagaimana adat kebiasan yang terjadi di masyarakat, bila ada salah seorang muslim meninggal maka keluarganya menggundang sanak kerabat dan handai taulan untuk berkumpul di rumah keluarga mayit untuk melakukan upacara selametan dan tahlil. Biasanya diadakan selama 7 hari berturut-turut, 40 harinya, 100 harinya, setelah setahun atau haulnya. Walimatul haml artinya selametan untuk wanita hamil. Dalam masyarakat jawa disebut tingkepan. Tingkepan menurut bahasa berarti upacara selametan tujuh bulan untuk wanita yang sedang hamil. daerah Jawa Timur bagian pantura, ada yang menyebut upacaya walimatul haml ini "Mrocoti", suatu bentuk tafa-ul, dimana calon bayi yang masih dalam kandungan lahir dengan selamat.

Tradisi walimatul haml sebagai ungkapan rasa sukur dalam menyambut berita gembira kehamilan dari pasangan suami istri, dalam masyarakat Jawa terdapat suatu tradisi berupa ritual yang khusus diperuntukkan bagi seorang wanita yang sedang menggandung, yaitu selamatan ngapati (saat kandungan berusia empat bulan), dan mitoni (pada saat usia kandungan genap enam atau tujuh bulan). Selametan ini disebut dengan tingkepan. Ada juga yang menyebut Mirocoti, yang merupakan bentuk tafaul, seraya mengharapkan agar 
janin dalam kandungan dan ibunya sehat, pada saat kelahirannya lancer, langsung keluar (procot, Jawa) tanpa ada kesulitan dan halangan apapun.

Saat janin berusia 120 hari atau 4 bulan di mulailah kehidupan dengan ruh, dan saat inilah ditentukan bagaimana ia berkehidupan selanjutnya, di dunia sampai diakhirat: ditentukan rizkinya, ajalnya, langkah-langkah perilakunya, dan sebagai orang yang celaka atau orang yang beruntung.

Maka menyongsong penentuan ini, hendaklah diadakan upacara ngapati yaitu berdoa (sebagai sikap bersyukur, ketundukan dan kepasrahan) mengajukan permohonan kepada Allah agar nanti anak lahir menjadi manusia yang utuh sempurna, yang sehat, yang di anugerahi rezeki yang baik dan lapang, berumur panjang yang penuh dengan nilai-nilai ibadah, beruntung di dunia dan di akhirat.

Kemudian setelah kelahiran berusia 7 bulan, yaitu ketika kandungan dirasakan sudah berbobot dan berbeban, maka diadakan lagi upacara yang disebut mitoni atau tingkepan. Dalam upacara mitoni ini disamping bersedekah juga diisi pembacaan doa, dengan harapan si bayi dalam kandungan diberikan keselamatan serta di takdirkan selalu dalam kebaikan kelak di dunia.

\section{Ritul Tolak Balak}

Upacara tolak balak dimaksud untuk menolak bahaya atau malapetaka bagi masyarakat. Upacara ini pada setiap masyarakat berbeda nama dan bentuknya. Seperti Sedekah, Nyadran, Laburan, Petik laut, Barikan, Klemen dan lain-lain. Upacara ini biasanya diselenggarakan di tempat angker atau keramat. Upacara ini di persembahkan kepada nenek Danyang yang menunggu tempat itu sebagai pelindung dan penjaga desa, supaya desanya terhindar dari mara bahanya. Upacara ini adalah komunal, sebagian masyarakat terlibat.

\section{Upacara Pertanian}

Upacara ini sangat akrab dengan masyarakat tani atau nelayan.Upacara ini dimaksudkan untuk mensyukuri hasil panen dan berharap panen yang akan datang akan lebih baik peruntungannya. Upacara ini biasanya meliputi individual dan komunal. Secara individu, masyarakat setiap menjelang tanam, tanaman berbuah, dan mejelang petik, atau panen, melakukan selametan secara sendiri di rumah atau di sawah masing-masing. Tetapi

ketika panen secara keseluruhan dianggap selesai, secara komunal, mereka secara bersama- 
sama mengadakan selametan lagi secara meriah, sebagai ungkapan syukur atas hasil yang diperoleh.

\section{Ritual Keluarga}

Masyarakat Kelurahan Rejomulyo memiliki ritual Keluarga, yang hanya berlaku bagi masing-masing keluarga. Tradisi tersebut disebut dengan Wetonan (Hari kelahiran), Jumat legian, dan Ruwatan.Ketiga tradisi tersebut hanya berlaku secara individual, artinya tidak semua keluarga melaksanakan tradisi tersebut.

Tradisi wetonan adalah ritual yang dilaksanakan untuk memperingati hari kelahiran seseorang di hari dan pasaran yang sama. Siklus ritual ini adalah 36 hari atau selapanan. Ritual ini biasanya dilaksanakan dengan cara sederhana, dengan menyajikan bubur merah dan putih untuk dimakan bersama dengan tetangga dan keluarga dekat.

Tradisi Jumat legian ini biasanya hanya dilaksanakan oleh kelompok Santri. Pelaksanaan ritual ini di rumah masing-masing, selepas Maghrib sampai Isya, dengan mengundang tetangga dekat, dengan menyajikan tumpeng sederhana atau kue Apem untuk dibacakan doa, dan kemudian dibawa pulang yang disebut dengan Berkat.

Ritual Ruwatan, ini biasanya hanya jika ada kasus tertentu atas keluarga. Jumlah anak dan urutan jenis kelamin anak akan menentukan ritual ini. Misalnya keluarga yang memiliki hanya 1 anak, baik laki maupun perempuan, ini disebut Untang-Anting. Anak yang berjumlah 2 orang, laki-laki dan perempuan, ini disebut gentono-gentini. Anak jumlah 3 orang, laki-laki, perempuan, laki-laki, ini disebut Sendang Kapit Pancuran, dan lain sebagainya. Kondisi ini dituntut untuk diadakan ruwatan, jika tidak maka keluarga tersebut akan mendapatkan kesulitan, atau anaknya akan dimakan Betoro Kolo. Ruwatan ini memakan biaya yang sangat besar, karena harus mengadakan pertunjukan Wayang kulit. Karena itu tidak semua keluarga mampu melaksanakannya. Sebagai gantinya, bagi yang tidak mampu hanya melaksanakan slametan dengan cara sederhana.

\section{Upacara Hari Besar Islam}

Upasara besar Islam ini meliputi Mauludan, Rejeban, Suroan, Riyoyo. Mauludan ini biasanya hanya membacakan Berzanji atau Diba'an yang isinya tidak lain adalah biografi dan sejarah kehidupan Rasulullah. Bisa juga ditambah dengan berbagai kegiatan keagamaan, seperti menampilkan kesenian Hadrah atau pengumuman hasil berbaagai lomba, sedang puncaknya ialah Mau'izhah Hasanah dari Muballig kondang. Sementara 
Rejeban hampir semua masyarakat menamakan yang sama. Kemudian Suroan, hampir semua masyarakat menamakan yang sama, hanya bentuknya yang berbeda, seperti gerebek Suro, tahun baru Hijriah, Suroan. Begitu pula ekspresi budaya tersebut berbeda antara masyarakat yang satu dengan yang lain. Riyoyo atau hari raya hampir seluruh masyarakat Indonesia merayakan hari itu. Setip selesai menjalankan ibadah Puasa Romadhon, masyarakat menyelenggarakan pesta rakyat yang disebut dengan hari raya Idul Fitri dan hari raya idul kurban untuk merayakan bulan Haji di bulan Dzulhijjah. Hari raya yang pertama biasanya masyarakat melakukannya dengan meriah dibanding dengan hari raya yang kedua.

Slametan siklus kehidupan yang meliputi kelahiran, perkawinan, kematian. Kemudian slametan sedekah, pertanian, dan tolak balak, semua waktu yang mendasari penetuan waktu adalah adanya system numerology, atau petulungan Jawa. Numerology yang dianggap berbelit-belit itu, terletak konsep metafisika orang Jawa yang fundamental. Petungan adalah suatu sistem harmoni untuk menyatakan suatu hubungan yang pas dan tepat. Sehingga manusia dapat menyesuaikan tindakannya dengan harmonis dengan kejadian alam. Jika tidak dapat menyesuaikan dengan petungan kejadian alam, maka manusia akan mendapatkan kesialan. Petungan atau numerologi lebih dikenal dengan Nogo Dino.

Makam juga menjadi tempat keramat. Di makam-makam Jawa kebanyakan diselenggarakan upacara manganan.Dalam upacaya ini, elemen masyarakat, kaum abagan, santri dan priyayi melakukan kegiatan upacara manganan dalam rangka melaksanakan tradisi lokal, membersikan makam dan mendoakan keluarga yang sudah meninggal. Seperti masyarakat yang datang ke makam Mbah Merojoyo, terutama kalangan abangan yang mempunyai tujuan untuk mendapatkan barokah ngelmu, kekayaan, dan untuk mendapat petunjuk dari masalah yang dihadapi dari Mbah Merojoyo.

\section{Nogo dino ( hitugan hari)}

Nogo Dino adalah Arah pantangan yang dikaitkan dengan hari.Ilmu ini jaman dulu sangat dipegang kuat oleh para Leluhur tanah jawa ini, terutama pada saat akan bepergian pasti dilihat Nogo Dinonya karena menurut kepercayaan bila kita melanggarnya pasti akan mendapatkan sial atau apes. Inilah arah pantangan/Nogo Dino itu SENIN = UTARA , SELASA $=$ TIMUR, RABU $=$ SELATAN, KAMIS $=$ BARAT, JUM'AT $=$ TIMUR, SABTU $=$ SELATAN, MINGGU = BARAT.Misal pada hari Senin Nogo Dinonya ada di 
Utara, maka pada hari itu kita tidak boleh bepergian ke arah utara. Kalau dilanggar akan kurang beruntung karena Hoky kita akan dicaplok oleh Nogo Dino yang ada diutara tadi.

\section{B. Peran Sosial Lembaga Pendikan Agama dalam Masyarakat}

Pendidikan Islam adalah sebagai lembaga terdiri dari tiga bentuk. Pertama, lembaga pendidikan informal yaitu yang berlangsung di rumah tangga. Kedua, lembaga pendidikan nonformal yang berlangsung di masyarakat, dan ketiga, lembaga pendidikan formal yang berlangsung di sekolah.Khusus lembaga pendidikan formal ada empat jenis bentuknya, yakni pesantren, sekolah, madrasah, dan pendidikan tinggi.

Pendidikan islam sebagai mata pelajaran adalah salah satu mata pelajaran yang diajarkan pada tingkat pendidikan dasar dan menengah serta tinggi. Pada lembaga-lembaga pendidikan tersebut mata pelajaran agama Islam diajarkan sejak Indonesia merdeka di sekolah-sekolah umum. Begitu juga sejak permulaan Tahun 1960-an masuknya pendidikan agama ke perguruan tinggi. Subjek keagamaan inilah yang dimaksudkan dengan pendidikan Islam sebagai mata pelajaran.

Dampak dari adanya Lembaga Pendidikan Agama di Kelurahan Rejo Mulyo misalnya:

\section{Dalam Bidang Ekonomi}

Dalam bidang ekonomi dirasa sangat membantu dalam meningkatkan pendapatan masyarat Rejomulyo yaitu membagun kos-kosan, warung makan, foto copy, rentalan. Disaat mahasiwa sedang liburan mereka semua pada pulang sehinga berdampak pada pendapatan masyarat Rejomulyo hal ini membuktikan bahwa dengan berdirinya lembaga tersebut sangat mempengaruhi pertumbuhan perekonomian masyarat karena konsumennya sebagian besar adalah siswa dari lembaga pendidikan yang ada.

\section{Dalam Bidang Sosial}

Peran Lembaga Pendidikan Agama dalam bidang sosial dapat kita lihat dari lembaga agama yang ikut serta dalam hal pembagian Daging Qurban, pembagian Zakat Fitrah, melakukan kerjabakti, ikut serta dalah acara Agustusan dan Mahasiswa yang meminta masyarakat untuk menabung yang bertujuan mengembangkan perekonomian masyarakat Kelurahan Rejomulyo.

3. Dalam Bidang Budaya 
Dari beberapa hal diatas ketika lembaga agama yang ada mampu memberikan peranannya dalam agama, ekonomi, sosial, bagi masarakat Rejomulyo akan tetapi peneliti disini dalam melakukan penelitian dan dari beberapa informan mengatakan bahwa peran lambaga agama tidak memiliki sedikitpun dalam hal memberikan pengaruh kebudayaan bagi masyarakat Kelurahan Rejomulyo.

\section{Dalam Bidang Agama}

Peran Lembaga Pedidikan Agama dalam bidang ke agamaan bagi masyarakat Rejomulyo dirasa oleh sebagian masyarakat kurang memberikan peranannya dalam beberapa hal seperti Yasinan, Tahlilan, Diba'an, pengajian Dzikrul Ghofilin, membagun sarana ibadah sedang peran lembaga tersebut yang dirasakan masyarakat hanya sebatas Khotbah Juam'at dan mengajar madrasah TPA.

Peran Santri, Abangan dan Priyayi terhadap Lembaga Pendidikan agama adalah sebagai objek untuk menyiarkan ajaran agama Islam dalam hal Khutbah Jum'at, pembagian infak dan sedekah. Jika tidak ada kelompok Santri, Abangan dan Priyayi tujuan Lembaga Pendidikan Agama tidak bisa berjalan dengan lancar.

Dari hasil pengamatan penelitian di lapangan di peroleh bahwa peran Lembaga Pendidikan Agama di dalam keberagaan masyarakat Rejomulyo terdapat peran sosial Lembaga Pendidikan Agama dalam meningkatkan nilai keagamaan masyarakat tapi peran tersebut kurang maksimal. Adapun peran sosial Lembaga Pendidikan Agama seperti: memberikan Zakat Fitrah, membagikan Daging Qurban kepada masyarakat dan ada Dosen yang berkutbah waktu hari Jum'at, tapi selama ini bantuan pembiyayaan dalam upaya meningkatkan kualitas agama masyarakat berupa uang belum ada.

a. Pembinaan moral spiritual

1) Pengajian rutin

Masyarakat Rejomuyo mempunyai kegiatan keagamaan rutin, yaitu pengajian Dzikrul Ghofilin yang diselenggarakan satu minggu sekali yang di laksanakan pada hari rabo malam yang di hadiri oleh masyarakat keluarahan Rejomulyo baik yang tua maupun yang muda. Kegiatan tersebut memiliki antusias yang cukup memuaskan karena dari sisi kuantitasnya. Dalam acara ritual kegiatan Dzikrul Ghofilin yang isinya meliputi pembacaan serangkaian kalimat Tahlil, kemudian diikuti dengan pembacaan Surat Al- Fatihah yang dibaca sebanyak seratus kali. Adapun yang dimaksud dengan Tahlil adalah mengucapkan kalimat Laa Ilaaha 


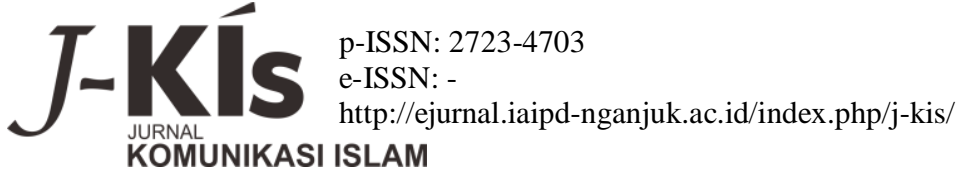

Illaa Allah. Menurut pengertian yang dipahami sehari-hari, tahlil artikan sebagai "membaca serangkaian surah-surah al-Qur'an, ayah-ayat pilihan, dan kalimatkalimat dzikir pilihan, yang diawali dengan membaca surah al-Fatihah dengan meniatkan pahalanya untuk arwah yang dimaksudkan oleh si pembaca atau oleh yang punya hajat, kemudian ditutup dengan do'a.

Inti do'a dalam kegiatan tahlil adalah memohon kepada Allah agar pahala bacaan al-Qur'an dan dzikir-dzikir pilihan lainnya disampaikan kepada arwah yang dimaksudkan pada khususnya dan kaum Muslimin pada umumnya, serta memohon pengampunan kepada Allah untuk arwah-arwah mereka. Peran Lembaga Pendidikan Agama (MTsN2, MAN2, STAIN Kediri) dalam pengajian rutin yang di laksanakan oleh masyarkat Rejomulyo masih belum ada.

2) Pembentukan petugas Khotib

Masyarakat Kelurahan Rejomulyo setiap jum'at melaksanakan ibadah sholat jum'at di masjid yang ada di sekitar tempat tinggal rumah warga, sholat Jum'at tersebut tidak hanya dihadiri oleh masyarakat kelurahan Rejomulyo saja tetapi juga dihadiri oleh Dosen, Mahasiswa, siswa MTsN2, siswa MAN2 dan sebagian kecil pedagang dari pasar grosir,juga terdapat bahwa ada khotib dari kampus STAIN Kediri, yaitu Bapak Ali Anwar, Bapak Anis Khumaidi, Bapak Zaenal Arifin, Bapak Syamsul Huda, dan Bapak Mu'tasim Billah dan Bapak Mukmin dan Bapak Ali Mursidi. beliau mengatakan bahwa dengan adanya Dosen yang memberi luangan waktunya untuk mengisi kutbah Jum'at dirasa mampu memberi suasana baru terhadap dakwah islam yang ada, dikarenakan beliau-beliau itu dianggap mumpuni dalam masalah keagamaan.

b. Pemberian infak dan sedekah

1) Bantuan langsung tunai

Dari hasil pengamatan penelitian di lapangan di peroleh bahwa peran Lembaga Pendidikan Agama (MTsN2, MAN2, STAIN Kediri) dalam hal bantuan secara langsung adalah pembagian Zakat Fitrah dan Daging Qurban yang diberikan kerumah warga yang dilaksanakan setahun sekali. Adapun pengertian dari Zakat Fitrah adalah zakat yang di berikan pada waktu hari Idhul Fitri dan pemberian danging kurban di berikan pada hari Raya Idhul Adha, bahwa sanya tidak ditemukan 
bantuan langsung tunai dari Lembaga Pendidikan Agama dalam upaya meningkatkan kualitas keagamaan masyarakat Rejomulyo.

2) Bantuan pembangunan sarana ibadah

Dari hasil pengamatan penelitian di lapangan di peroleh bahwa peran Lembaga Pendidikan Agama (MTsN2, MAN2, STAIN Kediri) dalam hal bantuan pembagunan sarana ibadah belum ada. Dalam hal pembangun sarana ibadah masyarakat hanya menggunakan dana dari suadaya masyarakat sekitar ada juga bantuan yang di berikan oleh Wali Kota Kediri yakni dalam rangka pembangunan Masjid Mujahidin.

\section{KESIMPULAN}

Sebagaimana yang telah diuraikan dalam bab - bab sebelumnya tentang bagaimana model keberagamaan masyarakat Rejomulyo di tengah-tengah lingkungan berkembangnya Lembaga Pendidikan Agama, maka dalam bab ini peneliti mengambil kesimpulan sebagai berikut :

1. Dari fenomena yang dapat diidentifikasi pada masyarakat Rejomulyo kecamatan kota Kediri praktek keagamaan yang ada dapat dikelompokkan kedalam bentuk-bentuk golongan sosial religius, menurut Clifford Geertz diantaranya Abangan, Santri, dan Priyayi. Tapi dalam hal kraktristiknya mengalami perubahan karena kelompok Abangan, Santri dan Priyayi masih mempercayai tradisi-tradisi selametan seperti apa yang di ajarkan oleh Wali Songo. Ia menggambarkan ketiga varian religious diantara orang-orang jawa sebagai berikut:

Sebagaian besar masyarakat Rejomulyo masih menjalankan ritual Abangan seperti apa yang di jelaskan oleh Clifford Geertz yang melakukan studinya di daerah Pare. Tradisi yang berkembang pada masyarakat Rejomulyo tidak diketahui kapan mulai berkembangnya. Karena generasi yang ada sekarang hanya mewarisi apa yang telah ada, dan mereka tingal mengamalkan dari apa yang menjadi tradisi dari nenek moyangnya. Di tengah-tengah lingkungan berkembangnya Lembaga Pendidikan Agama, masyarakat masih tetap berpegang teguh dengan nilai lama, yang digunakan untuk meneguhkan jati diri dan kepribadian masyarakat. Filosofi hidup orang Jawa ojo dumeh yang berarti mawas diri, dan tansah eling yang berarti selalu ingat terhadap tujuan hidup, member pedoman penting bagi masyarakat Jawa. Tradisi yang terdapat di masyarakat ada yang bertentangan dengan akidah Islam, tapi ada juga yang mendukung ajaran Islam. Hal ini tidak bisa dihindari, 
$\int \begin{aligned} & \text { p-ISSN: } 2723-4703 \\ & \text { e-ISSN: - } \\ & \text { http://ejurnal.iaipd-nganjuk.ac.id/index.php/j-kis/ } \\ & \text { KURNALUNIKASI ISLAM }\end{aligned}$

karena perjalanan sejarah masuknya Islam di nusantara akan mengalir kepada timbulnya sinkretisme budaya dan agama.

2. Peran sosial Lembaga Pendidikan Agama dalam meningkatkan nilai keagamaan masyarakat ada tapi, peran tersebut kurang maksimal. Karena antara lembaga pendidikan interaksinya hanya berupa pemberi dan penerima tetepi hanya sebatas dalam hal guru dan murid misalnya masyarakat di kelurahan Rejomulyo menyekolahkan anaknya ke lembaga pendidikan yang ada sedangkan apabila masyarakat tidak menyekolahkan anaknya ke lembaga pendidikan yang ada di Kelurahan Rejomulyo maka interaksinya juga tidak ada, tetapi peranya juga ada yang secara tidak langsung yakni berdirinya lembaga pendidikan juga memberi kesempatan lapangan kerja bagi warga Rejormulyo dengan bukti adanya tempat kos, warung makan dan terdapatnya pedagang kaki lima.

\section{DAFTAR PUSTAKA}

al Aziz, Saifulloh. Kajian Hukum-Hukum Walimah Selametan. Surabaya: Terbit Terang. 2009.

Amin, Darori. Islam dan Budaya Jawa. Yogyakarta: Gama Media. 2000.

An-Nabiry, Fathul Bahri. Dakwah Islam. Jakarta: AMZAH. 2008.

Chafid, et. al., Tradisi Islami. Surabaya: Khalista. 2006.

Damami, Mohammad. MAKNA AGAMA dalam MASYARAKAT JAWA. Yogyakarta: LESFI. 2002.

Daulay, Haidar Putra. PEMBERDAYAAN PENDIDIKAN ISLAM DI INDONESIA. Jakarta: Rineka Cipta. 2009.

Endraswara, Suwardi. Mistik Kejawen. Yogyakarta: Narasi. 2003.

Fattah, Munawir Abdul. TRADISI ORANG-ORANG NU. Yogyakarta: Pustaka Pesantren. 2006.

Geertz, Cliffort. Abang, Santri dan Priyayi dalam Masyarakat Jawa. Jakarta: Dunia Pustaka Jaya. 1989. 
Hendropuspito. Sosiologi Agama. Jakarta: Kanisius. 1992.

Isshomuddin. Pengantar Sosiologi Agama. Jakarta: Ghalia Indonesia. 2002.

Jahroni, Jamhari Jajang. Gerakan Salafi Radikal di Indonesia. Jakarta: PT RajaGrafindo Persada. 2004.

Jamil, Abdul. et. al., Islam dan Kebudayaan Jawa. Yogyakarta: Gama Media. 2002.

Kahmad, Dadang. Sosiologi Agama. Bandung: PT Remaja Rosdakarya. 2000.

Muchtarom, Zainal. Islam di Jawa. Jakarta: Selamba Diniyah. 2002.

Muhadjir, Neong. Metodologi Penelitian Kualitatif. Yogyakarta: Rake Sarasin. 1996.

Mulder, Niels. MISTISISME JAWA. Jogyakarta: Lkis Yogyakarta. 2001.

Narwoko, J. Dwi dan Bagong Suyanto, SOSIOLOGI TEKS PENGANTAR DAN TERAPAN. Jakarta: KENCANA PREDANA MEDIA GROUP. 2007.

Nottingham, Elizabeth K. AGAMA DAN MASYARAKAT: Suatu Pengantar Sosiologi Agama, terj. Abdul M. Naharong. Jakarta: PT Raja Grafindo Persada. 1997.

Sardjuningsih. Islam dalam Tradisi Lokal. Kediri: LP3M STAIN Kediri.

Scharf, Betty. R. Kajian Sosiologi Agama. Yogyakarta: PT Tiara Wacana. 1995.

Simuh, Mistik Islam Kejawen Raden Ngabehi Ranggawarsito. Jakarta: Universitas Indonesia. 1988.

Syam, Nur. Islam Pesisir. Yogyakarta: Lkis. 2005.

--------. Madzhab-Madzhab Antropologi. Jogyakarta:Lkis Yogyakarta. 2011.

Tim penyusun buku pedoman karya ilmiah. Pedoman karya ilmah. Kediri: STAIN Kediri. 2009.

Woodward, Mark R. Islam Jawa. Yogyakarta: Lkis Yogyakarta. 1999. 